Supplement of Biogeosciences, 13, 535-549, 2016

http://www.biogeosciences.net/13/535/2016/

doi:10.5194/bg-13-535-2016-supplement

(C) Author(s) 2016. CC Attribution 3.0 License.

(c) (i)

Supplement of

\title{
Unusual biogenic calcite structures in two shallow lakes, James Ross Island, Antarctica
}

\section{J. Elster et al.}

Correspondence to: J. Elster (jelster@ prf.jcu.cz)

The copyright of individual parts of the supplement might differ from the CC-BY 3.0 licence. 


\section{Supplement}

2 Figure S1. Relative frequency of hourly values of water temperature in lake 1 (a) and air 3 temperature in the Solorina Valley (b) from February 2009 to November 2010.

4

5 Figure S2. Occurrence of days with lake 1 water temperature (L1 water) higher than $-4{ }^{\circ} \mathrm{C}$ 6 complemented with monthly mean global solar radiation at Mendel Station both from 7 February 2009 to November 2010.

8

9 

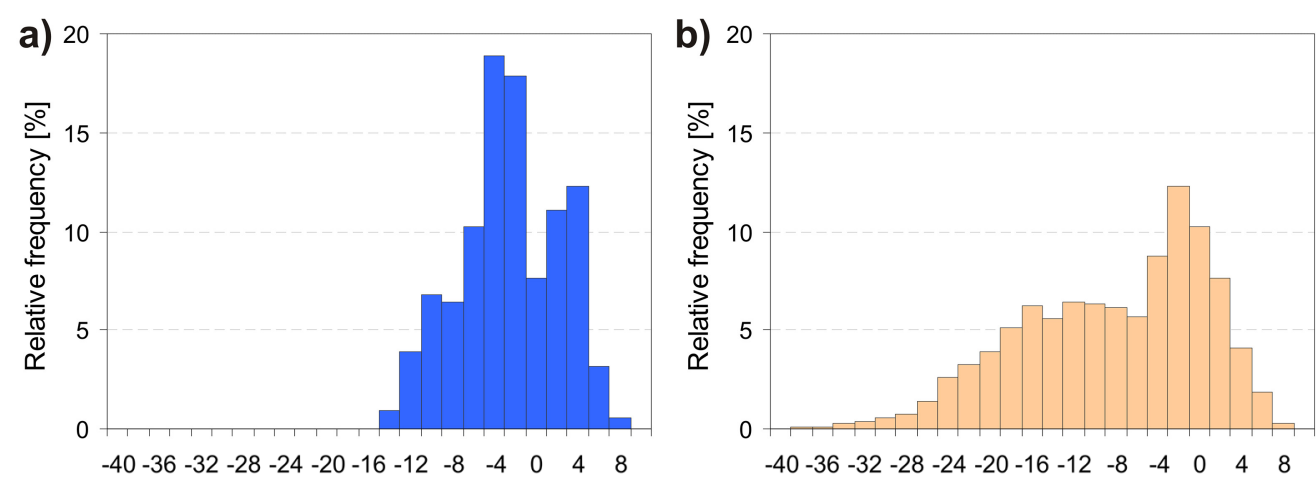

Lake1 water temperature $\left[{ }^{\circ} \mathrm{C}\right]$

Air temperature $\left[{ }^{\circ} \mathrm{C}\right]$ 


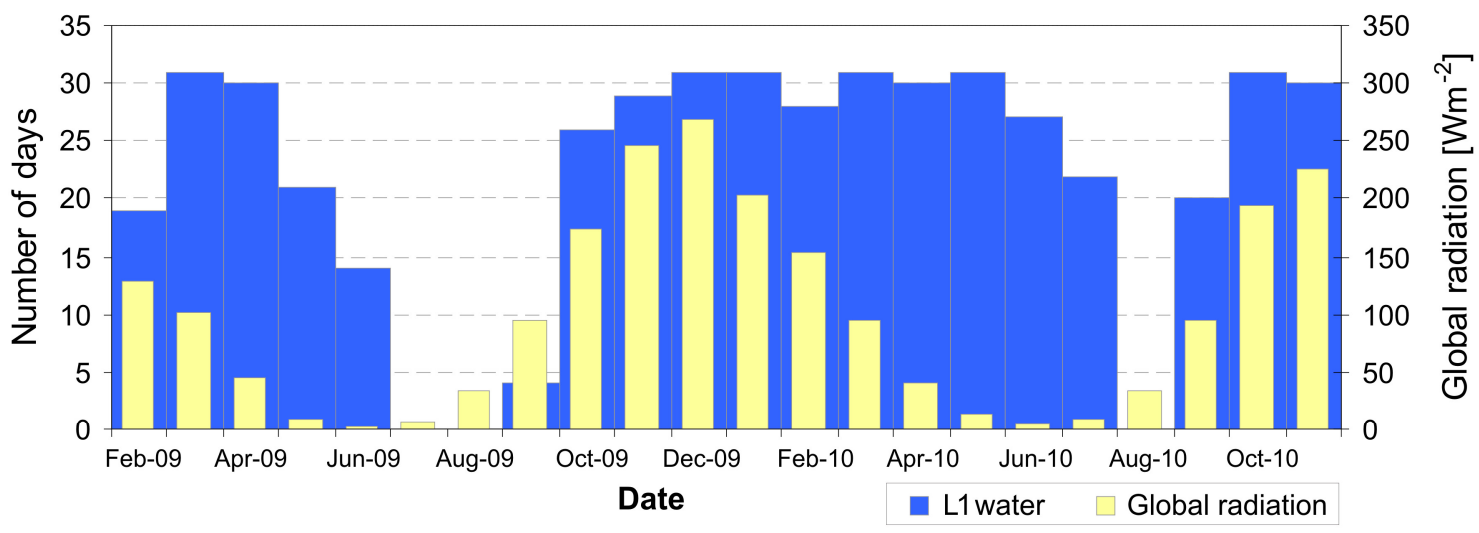

